\title{
Purification, biochemical characterisation, and mass spectrometry analysis of phenylalanine aminopeptidase from the shoots of pea plants
}

\author{
Magda Pyrzyna $\cdot$ Urszula Szawłowska • \\ Wiesław Bielawski $\cdot$ Edyta Zdunek-Zastocka
}

Received: 16 August 2010/Revised: 18 November 2010/Accepted: 21 December 2010/Published online: 13 January 2011

(C) The Author(s) 2011. This article is published with open access at Springerlink.com

\begin{abstract}
Phenylalanine aminopeptidase (Phe-AP) was isolated from the shoots of 3-week-old pea plants and purified to molecular homogeneity using a four-step purification procedure (ammonium sulphate precipitation, chromatography on DEAE-cellulose, phenyl-sepharose HP, and Protein-Pak Q 8HR HPLC columns). The enzyme was purified 513-fold with a recovery of $8 \%$. The molecular weight of the purified enzyme as determined by SDSPAGE and gel filtration was approximately $60 \mathrm{kDa}$, and the enzyme appeared to be a monomer. Its $\mathrm{pH}$ and temperature optimum were $\mathrm{pH} 7.5$ and $37^{\circ} \mathrm{C}$, respectively. The enzyme prefers substrates with $\mathrm{Phe}$ at the $\mathrm{N}$-terminus, although a high activity for substrates with $\mathrm{N}$-terminal Tyr, Trp, Leu, and Met was also observed. The activity with Leu- $\beta$-naphthylamide was at least two times lower than that with Phe- $\beta$-naphthylamide (Phe- $\beta$-NA). The $K_{\mathrm{m}}$ value for activity with Phe- $\beta$-NA was the lowest amongst the substrates tested, and it was $7.5 \times 10^{-5} \mathrm{M}$. The activity of Phe-AP was not inhibited by EDTA, 1,10-phenanthroline and pepstatin A. The most effective inhibitors were $p \mathrm{HMB}$ and E-64, which modify sulphydryl groups; however, a significant inhibition in the presence of DFP and PMSF, both of which are serine protease inhibitors, was also observed. By applying mass spectrometry analysis, the peptides derived from the purified Phe-AP were assigned to amino acid sequences of the leucine aminopeptidases of N-type (LAPs-N).
\end{abstract}

Communicated by G. Klobus.

M. Pyrzyna · U. Szawłowska ·

W. Bielawski · E. Zdunek-Zastocka $(\square)$

Department of Biochemistry, Warsaw University of Life

Sciences, SGGW, Nowoursynowska 159, 02-776 Warsaw,

Poland

e-mail: edyta_zdunek_zastocka@sggw.pl
Keywords Phenylalanine aminopeptidase . Purification - Substrate specificity · Inhibitors · Mass spectrometry analysis $\cdot$ Pea

\section{Introduction}

Aminopeptidases (EC 3.4.11) are exopeptidases that catalyse the cleavage of $\mathrm{N}$-terminal amino acids from proteins or peptides (Walling and $\mathrm{Gu}$ 1996). They constitute a diverse set of enzymes with important roles in the maintenance of cell homeostasis, growth, development, and defensive responses. Some of the aminopeptidases participate in general protein turnover, maturation of proteins, activation and inactivation of some regulatory molecules, mobilisation of storage proteins, and mobilisation of carbon and nitrogen reserves from senescing organs, whilst the biological functions of others has not yet been elucidated (Matsui et al. 2006; Walling 2006; Walling and Gu 1996).

Leucine aminopeptidases (LAP, EC 3.4.11.1) are the largest and most studied group of aminopeptidases in animals and microorganisms. Their nucleotide sequences and X-ray crystal structures have been discovered, and key residues for catalysis have been identified (Burley et al. 1990; Matsui et al. 2006; Rawlings et al. 2010; Taylor 1993; Walling and Gu 1996). These enzymes have also been observed in certain plant species; they have been identified and characterised in barley (Sopanen and Mikola 1975), Arabidopsis (Bartling and Weiler 1992; Bartling and Nosek 1994), potato (Herbers et al. 1994), and tomato (Gu et al. 1996, 1999; Gu and Walling 2000; Tu et al. 2003). They are oligomeric enzymes with molecular masses of over $250 \mathrm{kDa}$, comprised mainly of six identical subunits, and function optimally at alkaline $\mathrm{pH}$ (Bartling 
and Nosek 1994; Gu et al. 1999; Tu et al. 2003). LAPs are thermally stable proteins, and their activity depends on the presence of metal ions, which places them within the M17 peptidase family (Matsui et al. 2006; Rawlings et al. 2010; Walling 2006). Two types of LAP protomers have been identified in tomato, i.e., LAP-N (neutral pI) and LAP-A (acidic pI) (Gu et al. 1996). Subsequently, the LAP-N and LAP-A proteins were overexpressed in E. coli and characterised (Gu et al. 1999; Tu et al. 2003). The multimeric LAP-A preferentially hydrolyses substrates with Leu, Met, and Arg at the N-terminus, whereas LAP-N also cleaves $\mathrm{N}$-terminal Phe in a very efficient manner (Gu et al. 1999; $\mathrm{Tu}$ et al. 2003). Despite the high degree of identity (approximately $73-77 \%$ ) between the nucleotide and amino acid sequences of these protomers, they are characterised by different expression profiles. LAP-N-like proteins are present in all plant species examined, whilst LAPs-A have so far been shown to exist in only the solanaceous plants tomato and potato (Chao et al. 2000). Furthermore, LapN genes are expressed constitutively in all studied organs (Bartling and Nosek 1994; Chao et al. 2000; Tu et al. 2003), whereas the expression of LapA genes is induced during mechanical injury and in response to abscisic acid and jasmonic acid (Fowler et al. 2009; Gu et al. 1996; Herbers et al. 1994). By comparison of amino acid sequences of the known LAPs, 28 signature residues were identified ( $\mathrm{Tu}$ et al. 2003) that make it possible to classify LAP proteins as LAP-N or LAP-A-like.

In plants, there exists a larger and more ubiquitously expressed group of aminopeptidases than the oligomeric LAPs described above. These are monomeric enzymes with molecular weights ranging from 40 to $80 \mathrm{kDa}$ and a neutral $\mathrm{pH}$ optimum that preferentially cleave hydrophobic and other neutral amino acids from the N-terminus of the substrate (Walling and Gu 1996). Their activity is inhibited by heavy metals and reagents specific to $\mathrm{SH}$ groups. Amongst these enzymes, a group of aminopeptidases that show a striking preference for substrates with $\mathrm{N}$-terminal aromatic amino acids, mainly phenylalanine, ought to be distinguished. Aromatic aminopeptidases are characterised by low $K_{\mathrm{m}}$ values against substrates with Phe, Trp, or Tyr (but mainly Phe) at the $\mathrm{N}$-terminus, a considerable but significantly lower activity against Leu or Met, and little or undetectable activity against Gly, Ala, Glu, Arg, or Lys (Kang et al. 1999; Kolehmainen and Mikola 1971; Tishinov et al. 2009; Vodkin and Scandalios 1980; Waters and Dalling 1984; Wynn and Murray 1985; Yamaoka et al. 1994). Most of these enzymes are also partially inhibited by serine protease inhibitors, and their activities remain unchanged in the presence of metal chelators (Kang et al. 1999; Ogiwara et al. 2005; Tishinov et al. 2009; Yamaoka et al. 1994). There is no sequence (amino acid or nucleotide) or crystallographic data available for any of the members of this thiol-dependent group of plant aminopeptidases, which considerably hinders the establishment of their phylogenetic relations with other proteins and their proper classification. Some authors consider the enzymes to be leucine aminopeptidases, based on their ability to hydrolyse substrates with N-terminal Leu (Collier and Murray 1977; Ogiwara et al. 2005); however, these proteins are vastly different in terms of structure, sensitivity to inhibitors, and catalytic properties.

Here, we report the purification and biochemical characterisation of an aromatic aminopeptidase (Phe-AP), which prefers substrates with $\mathrm{N}$-terminal Phe, from the shoots of 3 -week-old pea plants. This aminopeptidase has all the features characteristic of the as yet unclassified, and in the majority of cases still incompletely characterised, aromatic aminopeptidases, which makes it an appropriate representative of this enzyme group. Despite the differences in catalytic properties between leucine and aromatic aminopeptidases, the Phe-AP peptides were assigned to amino acid sequences of the leucine aminopeptidases of N-type (LAPs-N) as obtained by mass spectrometry analysis.

\section{Materials and methods}

\section{Plant material}

Seeds of Pisum sativum L. (cv. Little Marvel) were germinated in moist vermiculite for 12 days, and the seedlings were transferred to containers filled with aerated half-strength Hoagland nutrient solution (Hoagland and Arnon 1938). The seedlings were grown in a growth chamber with temperatures of $22^{\circ} \mathrm{C}$ during the daytime and $18^{\circ} \mathrm{C}$ during the night, a 16-h photoperiod, $80 \%$ relative humidity, and a midday photosynthetic photon flux density of about $400 \mu \mathrm{E} \mathrm{m}^{-2} \mathrm{~s}^{-1}$. Shoots of 3-week-old plants were harvested and stored at $-80^{\circ} \mathrm{C}$ prior to extraction.

Enzyme extraction and purification

All steps of enzyme extraction and purification were performed at $4^{\circ} \mathrm{C}$. Shoots of pea plants $(30 \mathrm{~g})$ were ground in $90 \mathrm{~mL}$ of ice-cold extraction buffer $(50 \mathrm{mM}$ Tris- $\mathrm{HCl}$ buffer, pH 7.5 containing $2 \mathrm{mM}$ 2-mercaptoethanol). The homogenate was filtered through two layers of miracloth, and centrifuged for $30 \mathrm{~min}$ at $20,000 \times g$. The resulting supernatant was brought to $30 \%$ saturation with ammonium sulphate and centrifuged for $30 \mathrm{~min}$ at $20,000 \times g$. The precipitate was removed and ammonium sulphate was added to the supernatant to reach $60 \%$ saturation. The precipitate was collected by centrifugation, resuspended in $5 \mathrm{~mL}$ of buffer A $(10 \mathrm{mM}$ Tris- $\mathrm{HCl}$ buffer, pH 7.5 containing $2 \mathrm{mM}$ 2-mercaptoethanol), and dialysed overnight against the same 
buffer. The desalted samples was then concentrated with an Amicon (Millipore Corporation, Bedford, USA) ultrafiltration cell using a PM 10 membrane and loaded onto a DEAE-cellulose anion-exchange column $(2.6 \times 30 \mathrm{~cm})$ equilibrated with buffer A. The column was washed with buffer A, and the bound proteins were eluted with a linear gradient of 0 to $0.4 \mathrm{M} \mathrm{NaCl}$ at a flow rate of $1 \mathrm{~mL} \times \mathrm{min}^{-1}$. The fractions that were active against Phe- $\beta$-NA were pooled, concentrated by ultrafiltration, and applied to a phenyl-sepharose HP $(1.5 \times 14 \mathrm{~cm})$ column equilibrated with buffer A containing $2 \mathrm{M}$ ammonium sulphate (buffer B). The column was washed with buffer B, and the bound proteins were eluted with a linear gradient of 2-0 M ammonium sulphate at a flow rate of $1 \mathrm{~mL} \times \mathrm{min}^{-1}$. The fractions that were active against Phe- $\beta$-NA were pooled, concentrated by ultrafiltration, and fractionated by HPLC on a Protein-Pak Q 8HR anion-exchange column (Waters, Milford, USA) equilibrated with buffer A. The bound proteins were eluted with a linear gradient of $0-0.25 \mathrm{M} \mathrm{NaCl}$.

Aminopeptidase activity assay

Enzyme activity was determined according to the method of Kolehmainen and Mikola (1971) using amino acid$\beta$-naphthylamides ( $\beta$-NA) or amino acid- $p$-nitroanilides $(p$-NA) as substrates. In the routine assay, the reaction was carried out in $0.5 \mathrm{~mL}$ of $50 \mathrm{mM}$ Tris- $\mathrm{HCl}$ buffer $(\mathrm{pH} 7.5)$ containing $1 \mathrm{mM}$ substrate for $30 \mathrm{~min}$ at $37^{\circ} \mathrm{C}$. Released $\beta$-naphthylamine was coupled to Fast Garnet GBC at $\mathrm{pH}$ 4.2 , and the absorbance at $525 \mathrm{~nm}$ was measured. One unit of enzyme activity was defined as the release of $1 \mu \mathrm{mol}$ of free $\beta$-naphthylamine in $1 \mathrm{~min}$.

\section{Native PAGE and activity staining}

Polyacrylamide gel electrophoresis (PAGE) was performed under non-denaturing conditions in $7.0 \%$ polyacrylamide gels according to the method of Laemmli (1970) in the absence of SDS. After electrophoresis, the gels were incubated for $40 \mathrm{~min}$ at $37^{\circ} \mathrm{C}$ in $50 \mathrm{mM}$ Tris- $\mathrm{HCl}$ buffer (pH 7.5) containing $5 \mathrm{mM}$ Phe- $\beta$-NA and stained with $0.1 \% \mathrm{w} / \mathrm{v}$ Fast Garnet GBC dissolved in $1 \mathrm{M}$ sodium acetate (pH 4.2; Kolehmainen and Mikola 1971).

Molecular mass estimation

The molecular weight of the native enzyme was determined by gel filtration on a Sephadex G-200 column $(2.6 \times 100 \mathrm{~cm})$ equilibrated with $50 \mathrm{mM}$ Tris- $\mathrm{HCl}$ buffer (pH 7.5) containing $2 \mathrm{mM} 2$-mercaptoethanol. The column was calibrated with bovine serum albumin $(66 \mathrm{kDa})$, ovalbumin (45 kDa), carbonic anhydrase $(31 \mathrm{kDa})$, and cytochrome $c(12 \mathrm{kDa})$ as molecular weight standards. The eluted fractions were assayed for enzyme activity using Phe- $\beta$-NA as a substrate.

The molecular weight was also estimated under denaturing conditions by sodium dodecyl sulphate-polyacrylamide gel electrophoresis (SDS-PAGE), which was carried out according to the procedure of Laemmli (1970) in 12\% polyacrylamide slab gels. Proteins in the gel were stained with the colloidal Coomassie stain Roti Blue (Carl Roth, Germany).

Determination of protein concentration

Total soluble protein concentration was determined using the method of Bradford (1976) with bovine serum albumin as a standard. Protein content throughout the purification procedure was monitored spectrophotometrically at $280 \mathrm{~nm}$.

\section{Michaelis-Menten constant determination}

The $K_{\mathrm{m}}$ values for Phe-AP (AP1) against Phe- $\beta$-NA, Leu$\beta$-NA, Tyr- $\beta$-NA, and Trp- $\beta$-NA were calculated according to the standard Lineweaver-Burk (1934) procedure. The substrate concentrations used were in the range from 0.015 to $1.5 \mathrm{mM}$. Standard deviation was $<7 \%$ of the corresponding mean value in all cases.

Mass spectrometry analysis

Identification of the peptides derived from the purified Phe-AP (AP1) protein was determined by LC-MS/MS (liquid chromatography-tandem mass spectrometry) at the Mass Spectrometry Laboratory, The Institute of Biochemistry and Biophysics, Warsaw, Poland. In brief, a protein sample previously digested using trypsin was separated on a nanoAcquity UPLC (Ultra Performance LC) system and analysed with an Orbitrap-based mass spectrometer.

\section{Results}

Enzyme purification

Phenylalanine aminopeptidase (Phe-AP) was isolated from shoots of 3-week-old pea plants and purified to apparent homogeneity by a four-step purification procedure (ammonium sulphate precipitation, anion-exchange chromatography, hydrophobic chromatography, and high-performance anion-exchange chromatography). The results of the purification procedure are summarised in Table 1. The applied procedure resulted in a 513-fold purified enzyme preparation with a recovery of $8 \%$. Anion-exchange chromatography on a DEAE-cellulose and on a Protein-Pak Q 8HR (HPLC) column appeared to be the most effective 
Table 1 Summary of the purification of Phe-AP (AP1) isolated from shoots of 3-week-old pea plants

\begin{tabular}{lcccrr}
\hline Purification step & $\begin{array}{l}\text { Total activity } \\
\text { (units) }\end{array}$ & $\begin{array}{l}\text { Total protein } \\
(\mathrm{mg})\end{array}$ & $\begin{array}{l}\text { Specific activity } \\
\text { (units } \times \mathrm{mg}^{-1} \text { protein) }\end{array}$ & $\begin{array}{l}\text { Recovery } \\
(\%)\end{array}$ \\
\hline Crude extract & 244.3 & $1,655.53$ & 0.147 & 100.0 \\
Purification \\
30-60\% $\left(\mathrm{NH}_{4}\right)_{2} \mathrm{SO}_{4}$ & 189.7 & 429.78 & 0.441 & 77.6 & 1.0 \\
DEAE-cellulose & 54.0 & 14.07 & 3.837 & 22.1 & 3.0 \\
Phenyl-sepharose HP & 23.8 & 2.85 & 8.351 & 9.7 & 5.1 \\
Protein-Pak Q 8HR & 19.6 & 0.26 & 75.385 & 5.0 & 512.8 \\
\hline
\end{tabular}

Activity was assayed with Phe- $\beta$-NA as substrate

steps of the purification, which separated pea aminopeptidases from the bulk of the shoot proteins and resulted in a 8.7- and 9-fold purification of the enzyme preparation, respectively.

Only the last step of enzyme purification (performed on a Protein-Pak Q 8HR column) separated Phe-AP (AP1), an aminopeptidase with the highest preferences for Phe- $\beta$-NA, from AP2, an aminopeptidase with broad substrate specificity (Fig. 1). AP2 accepted as substrate not only Phe$\beta$-NA, Tyr- $\beta$-NA, and Leu- $\beta$-NA but also Ala- $\beta$-NA and Arg- $\beta$-NA. Native PAGE of the final Phe-AP preparation and subsequent staining with Phe- $\beta$-NA as substrate revealed one activity band corresponding to a single protein band on a gel stained with colloidal Coomassie blue (Fig. 2).

To confirm the homogeneity and determine the molecular weight of the purified enzyme, the final Phe-AP preparation was applied to a Sephadex G-200 chromatography and analysed by SDS-PAGE. The molecular weight of the enzyme determined by SDS-PAGE was approximately $61 \mathrm{kDa}$ (Fig. 3) and that of the native enzyme was $58.5 \mathrm{kDa}$, as estimated by gel filtration. The close correspondence between the molecular weights determined under native and denaturing conditions suggests that Phe-AP is a monomer.

\section{Characteristics of the enzyme}

The final homogenous Phe-AP preparation was used for biochemical characterisation of the enzyme. Substrate specificity and $K_{\mathrm{m}}$ values were determined with amino acid$\beta$-naphthylamides and amino acid- $p$-nitroanilides under standard aminopeptidase activity assay conditions. Amongst the substrates tested, the most preferred was that with Phe at the N-terminus, although a high activity with Met- $p$-NA was also observed (Table 2). However, the enzyme did hydrolyse also substrates with N-terminal Tyr, Trp, and Leu residues, albeit with a twofold lower efficiency. The highest Phe-AP activity in the presence of Phe- $\beta$-NA was accompanied by the lowest $K_{\mathrm{m}}$ value for that substrate when compared with that for other $\beta$-naphthylamides. Thus, we named the purified AP1 aminopeptidase phenylalanine aminopeptidase. The activity against the other substrates used was minimal and did not exceed $5 \%$ of the maximal activity.

The optimal $\mathrm{pH}$ for the catalytic action of Phe-AP was 7.5, as determined using both Britton-Robinson buffer (in the $\mathrm{pH}$ range of 6.5-9.0) and Tris- $\mathrm{HCl}$ buffer (in the $\mathrm{pH}$ range of 7-9.5; Fig. 4). A significant decrease in Phe-AP activity was observed below $\mathrm{pH} 7$ and above $\mathrm{pH} 8$.

The enzyme was active in the tested temperature range from 20 to $45^{\circ} \mathrm{C}$ with maximal activity at $37^{\circ} \mathrm{C}$ (Fig. 5). At
Fig. 1 Separation of aminopeptidases from shoots of pea plants on a Protein-Pak Q 8 HR column. The bound proteins were eluted in a linear gradient of $0-0.25 \mathrm{M} \mathrm{NaCl}$. Protein content in the eluate was monitored by UV absorbance at $280 \mathrm{~nm}$. Aminopeptidase activity in each fraction was assayed with amino acid- $\beta$ naphthylamides as described in "Materials and methods"

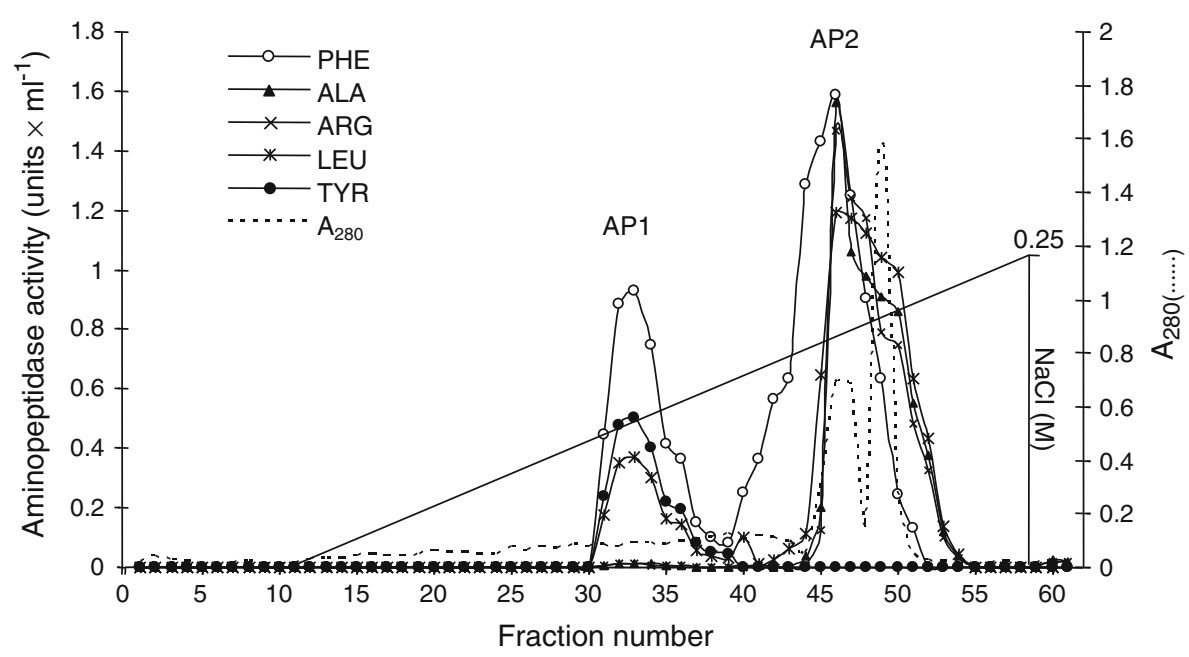




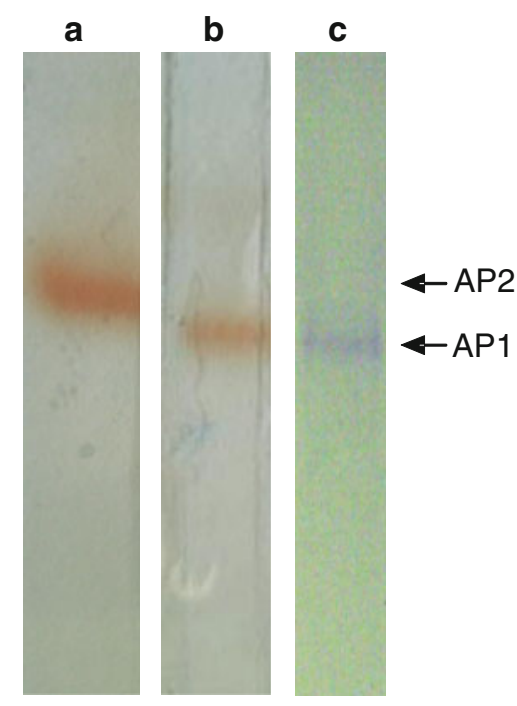

Fig. 2 Native PAGE analysis of the final enzyme preparation obtained on a Protein-Pak Q 8HR column. a Activity band of AP2 (an aliquot of the combined 43-50 fractions), b activity band of PheAP (AP1; an aliquot of the combined 33-38 fractions), c protein band of the homogenous Phe-AP stained with colloidal Coomassie blue. Activity in the gel was assayed using Phe- $\beta$-NA as a substrate

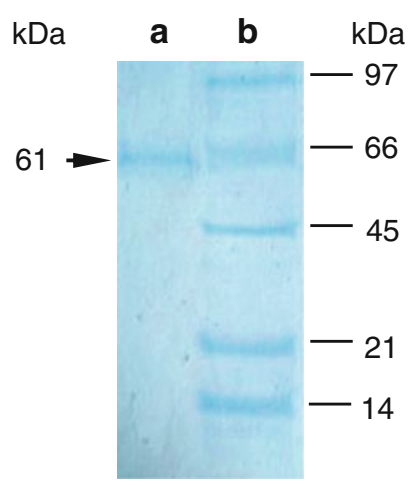

Fig. 3 Estimation of molecular weight of the purified Phe-AP (AP1) by SDS-PAGE. a An aliquot of the final Phe-AP (AP1) preparation, b molecular weight standards: phosphorylase b $(97 \mathrm{kDa})$, albumin $(66 \mathrm{kDa})$, ovalbumin $(45 \mathrm{kDa})$, trypsin inhibitor $(21 \mathrm{kDa})$, and lysozyme $(14 \mathrm{kDa})$

$40^{\circ} \mathrm{C}$, the activity was lower than the maximum by $35 \%$, whilst total inactivation of the enzyme occurred at $60^{\circ} \mathrm{C}$. Thermal stability of the purified enzyme was investigated in the range of $0-60^{\circ} \mathrm{C}$, and the remaining Phe-AP activity was determined after different pre-incubation times $(0,15$, 30, 45 and 60 min; Fig. 6). The enzyme was most stable at the range of $0-4^{\circ} \mathrm{C}$, as determined after $15 \mathrm{~min}$ of pre-incubation, and showed a sharp activity decline when the temperature was raised above $10^{\circ} \mathrm{C}$ (data not shown). Pre-incubating the enzyme for $15 \mathrm{~min}$ at $45^{\circ} \mathrm{C}$ decreased Phe-AP activity by almost $60 \%$, whilst pre-incubation at $40^{\circ} \mathrm{C}$ and $33-37^{\circ} \mathrm{C}$ decreased it by 35 and $10-15 \%$,
Table 2 Substrate specificity and kinetic parameters of Phe-AP (AP1)

\begin{tabular}{lrl}
\hline Substrate & Relative activity $(\%)$ & $K_{m}(\mathrm{M})$ \\
\hline Phe- $\beta$-NA & 100.0 & $7.5 \times 10^{-5}$ \\
Tyr- $\beta$-NA & 54.6 & $1.0 \times 10^{-4}$ \\
Leu- $\beta$-NA & 41.1 & $3.8 \times 10^{-4}$ \\
Trp- $\beta$-NA & 29.9 & $0.5 \times 10^{-4}$ \\
Ala- $\beta$-NA & 3.2 & \\
Arg- $\beta$-NA & 1.3 & \\
Gly- $\beta$-NA & 1.2 & \\
Pro- $\beta$-NA & 3.7 & \\
Asp- $\beta$-NA & 4.0 & \\
Glu- $\beta$-NA & 4.6 & \\
Phe- $p$-NA & 100.0 & \\
Met- $p$-NA & 99.0 & \\
Ala- $p$-NA & 5.6 & \\
\hline
\end{tabular}

The hydrolysis of different amino acid- $\beta$-naphthylamides and amino acid- $p$-nitroanilides was measured and compared with that of Phe$\beta$-NA or Phe- $p$-NA (taken as $100 \%$ )

$K_{\mathrm{m}}$ values were calculated according to the Lineweaver and Burk (1934) standard procedure

Standard deviation was $<7 \%$ of the corresponding mean value in all cases

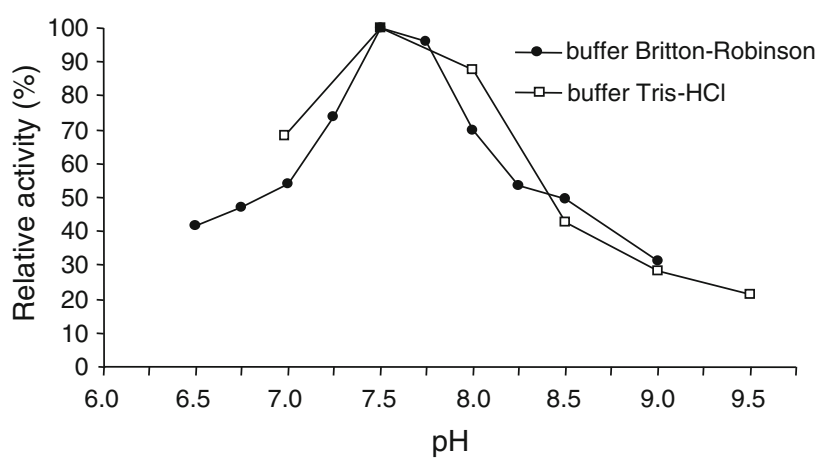

Fig. 4 Effect of $\mathrm{pH}$ on activity of the purified Phe-AP (AP1). Enzyme activity was determined with Phe- $\beta$-NA as substrate at the indicated $\mathrm{pH}$, and was reported as relative activity. The buffer systems were the following: $50 \mathrm{mM}$ Britton-Robinson buffer for the $\mathrm{pH}$ range of 6.5-9.0 and $50 \mathrm{mM}$ Tris- $\mathrm{HCl}$ buffer for the $\mathrm{pH}$ range of 7.0-9.0

respectively. After 60 min of pre-incubation at 45, 40, and $33-37^{\circ} \mathrm{C}$, the activity was lower by 95,65 , and $40-50 \%$, respectively.

The chelating agents EDTA and 1,10-phenanthroline were found to be ineffective as inhibitors of Phe-AP (Table 3). Interestingly, the enzyme activity was actually slightly enhanced in the presence of these compounds. This may be due to the removal of heavy metal ions by the chelators; these ions may inhibit Phe-AP when present in the reaction environment. Pepstatin A, an aspartic protease inhibitor, was also proved to be ineffective as an inhibitor. Significant (74\%) inhibition of Phe-AP activity occurred in 


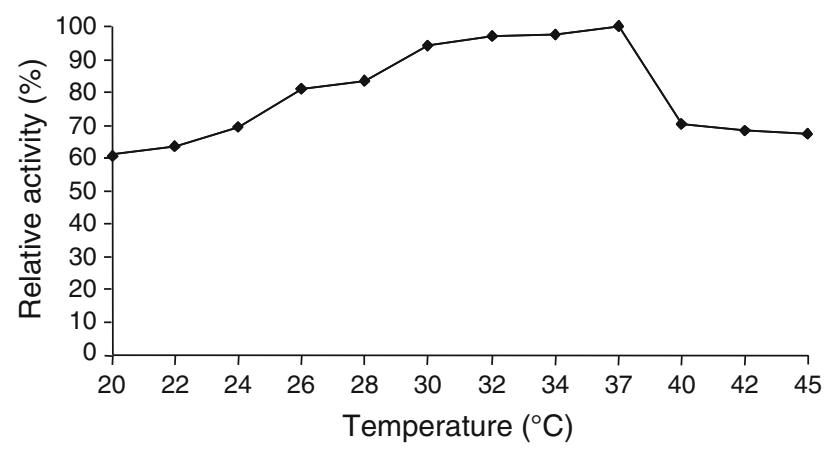

Fig. 5 Effect of temperature on activity of the purified Phe-AP (AP1). Enzyme activity was determined at indicated temperatures with Phe- $\beta$-NA as substrate and was reported as relative activity

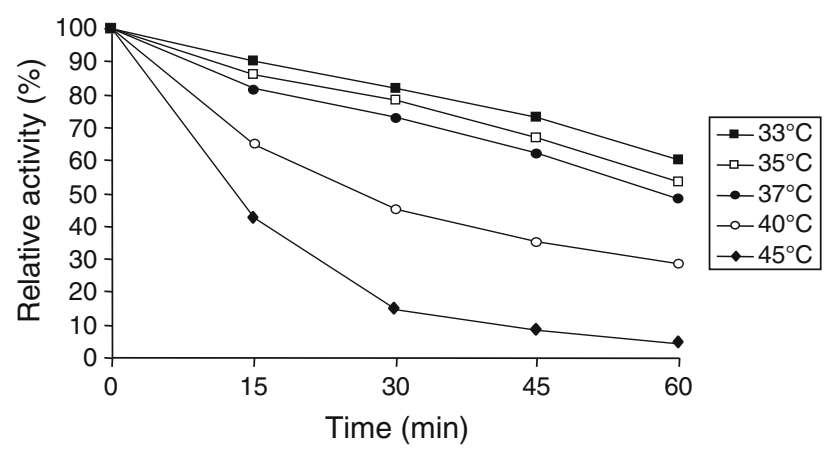

Fig. 6 Thermal stability of the purified Phe-AP (AP1). Prior to the activity assay, aliquots of the purified enzyme were incubated at the indicated temperatures for $15,30,45$, and 60 min. The residual AP activity was determined with Phe- $\beta$-NA as substrate

Table 3 Effect of protease inhibitors on the purified Phe-AP (AP1) activity

\begin{tabular}{llc}
\hline Inhibitor & Concentration $(\mathrm{mM})$ & Relative activity $(\%)$ \\
\hline None & - & 100 \\
1,10-Phenanthroline & 10.0 & 110 \\
EDTA & 10.0 & 108 \\
Pepstatin A & 0.15 & 103 \\
PMSF & 1.0 & 26 \\
DFP & 0.001 & 45 \\
& 0.01 & 28 \\
& 0.1 & 0 \\
$p$ HMB & 0.1 & 5 \\
E-64 & 0.001 & 44 \\
& 0.01 & 29 \\
& 0.1 & 0
\end{tabular}

The enzyme was pre-incubated in $50 \mathrm{mM}$ Tris-HCl buffer ( $\mathrm{pH} 7.5$ ) containing different inhibitors for $60 \mathrm{~min}$ at room temperature; Phe- $\beta$ NA was then added and the enzymatic reaction was performed at $37^{\circ} \mathrm{C}$

the presence of PMSF (phenylmethylsulfonic fluoride), a serine protease inhibitor. However, the most effective inhibitors were $p \mathrm{HMB}$ ( $p$-hydroxymercuribenzoate) and E-64
[(trans-epoxysuccinyl-L-leucylamido-(4-guanidino)butane)], which attack sulphydryl groups, and DFP (diisopropyl fluorophosphate), a serine protease inhibitor. All three inhibitors caused a total loss of Phe-AP activity at a concentration of $0.1 \mathrm{mM}$.

Mass spectrometry analysis of the Phe-AP peptides

By exploiting the peptides obtained after digestion of purified Phe-AP by trypsin and applying a mass spectrometric approach (LC-MS/MS) to analyse them, the similarity to the amino acid sequences of proteins available in database was sought. The highest degree of similarity observed was that obtained with the amino acid sequence of cytosolic aminopeptidase from Arabidopsis thaliana (AtLAP1, GenBank accession no. NP_179997, which is identical to that translated from the nucleotide sequence of no. X63444; Fig. 7). This aminopeptidase, according to the criteria proposed by Tu et al. (2003), belongs to the LAP-N group of plant enzymes. The peptides derived from Phe-AP cover $40.2 \%$ of the AtLAP1 sequence. Based on the crystal structures of bovine and E. coli LAP, the residues of multimeric LAP with proposed roles in catalysis and coordinating zinc ions have been identified and appeared to be conserved in animals, plants, and bacteria $(\mathrm{Gu}$ and Walling 2002; Kim and Lipscomb 1994; Tu et al. 2003). Four of the 5 zinc-binding residues (Lys 288, Asp 313, Asp 373, and Glu 375 in AtLAP1), one of the 2 residues involved in catalysis (Arg 377 in AtLAP1), and 8 of the 28 residues characteristic of LAP-N polypeptides ( $\mathrm{Tu}$ et al. 2003) were also observed in the sequences to which the Phe-AP peptides were assigned (Fig. 7), although their possible role in functioning of Phe-AP remains to be clarified.

\section{Discussion}

In the present study, the isolation, biochemical characterisation, and the putative partial amino acid sequence of phenylalanine aminopeptidase from pea shoots is reported. This enzyme belongs to the family of aminopeptidases that preferentially hydrolyse the substrates with N-terminal aromatic amino acids. Despite a number of publications that confirm the existence of this group of enzymes, no one has so far undertaken to define aromatic aminopeptidases as a separate group (Elleman 1974; Kang et al. 1999; Kolehmainen and Mikola 1971; Ogiwara et al. 2005; Tishinov et al. 2009; Vodkin and Scandalios 1980; Waters and Dalling 1984). Instead, based on their ability to hydrolyse Leu- $\beta$-naphthylamide and Leu- $p$-nitroanilide substrates, these enzymes are often categorised as leucine aminopeptidases (EC 3.4.11.1; Collier and Murray 1977; 
Fig. 7 Alignment of the peptides derived from pea PheAP (AP1) with the deduced amino acid sequence of leucine aminopeptidase from

Arabidopsis thaliana (AtLAP1; GenBank accession no. X63444). Sequences of the peptides derived from Phe-AP were determined by mass spectrometry. Asterisks denote coordination sites for $\mathrm{Zn}^{2+}$, and solid circles represent Lys and Arg residues in the catalytic site of Arabidopsis, bovine, and tomato LAPs (assigned according to Burley et al. 1990; Bartling and Weiler 1992; Gu and Walling 2002)
AtLAP 1
Phe-AP
MAHTLGLTQPNSTEPHKISFTAKEIDVIEWKGDILVVGVTEKDLAKDGNSKFENPILSKV 60
AtLAP 1
Phe-AP
AtLAP1
Phe-AP
AtLAP 1
Phe-AP
AtLAP1
Phe-AP
AtLAP1
Phe-AP
AtLAP1
Phe-AP
AtLAP1
Phe-AP
AtLAP1
Phe-AP
-------TQPNSTEPHKISFTAKE IDVIEWKR----------------SKFENPILSKV 36
DAHLSGLLAQVSSEEDFTGKPGQSTVLRLPGLGSKRIALIGLGQSVSSPVAFHSLGEAVA 120 DAHLSGLLAQVSSEEDFTGKPGQSTVLR---------------------------- 66
TVSKASQSTSAAIVLASSVSDESKLSSVSALASGIVLGLFEDGRYKSESKKPSLKAVDI I 180

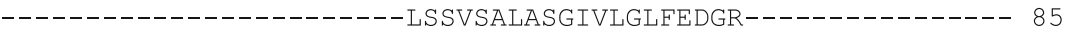
GFGTGAEVEKKLKYAEDVSYGVIFGRELINSPANVLTPAVLAEEAAKVASTYSDVFTANI 240

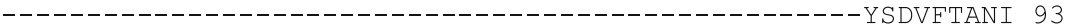
LNEEQCKELKMGSYLAVAAASANPPHFIHLVYKPPNGSVKTKLALVGKGLTFDSGGYNIK 300

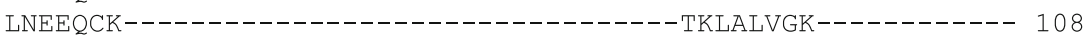 $* \quad * \quad \bullet$
TGPGCSIELMKFDMGGSAAVLGAAKAIGEIKPPGVEVHFIVAACENMISGTGMRPGDVIT 360 ----CS IELMKE DMGGSAAVLGAAKAIGER---GVEVHFIVAACENMISGTGMR------ 155 $*$
ASNGKTIEVNNTDAEGRLTLADALVYACNQGVDKIVDLATLTGACVIALGTSMAGIYTPS 420

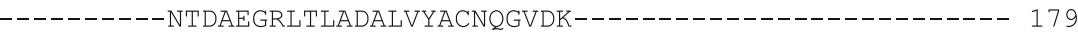 $* * \bullet$
DELAKEVIAASERSGEKLWRMPLEESYWEMMKSGVADMVNTGGRAGGS ITAALFLKQFVS 480

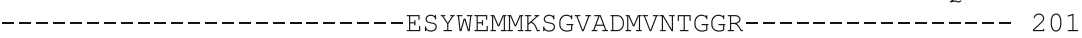
EKVQWMHIDMAGPVWNEKKKSGTGFGVATLVEWVQKNSSS 520 --------AGPVWNEKKK----------------- 209

Ogiwara et al. 2005). However, these hexameric enzymes are very different in their structure, catalytic properties, and inhibitor sensitivities from the monomeric thiol-dependent aromatic plant aminopeptidases described here. Discussed below are the similarities and differences within the aromatic aminopeptidase group and with respect to leucine aminopeptidases, towards which the partial amino acid sequence of Phe-AP purified from pea shoots displayed the highest degree of similarity.

By applying an original four-step purification procedure (Table 1), it was possible to obtain a Phe-AP enzymatic preparation of a very high degree of purity. The Phe-AP from pea shoots was purified to homogeneity 513-fold. It needs to be emphasised that only in some studies was a homogenous enzyme investigated (Elleman 1974; Tishinov et al. 2009); in the majority of cases enzyme activity was observed and characterised in crude, partially purified, or considerably purified extracts (Collier and Murray 1977; Kolehmainen and Mikola 1971; Ogiwara et al. 2005; Wynn and Murray 1985). Unfortunately, due to the low stability of the enzyme, each stage of purification caused a drop in the total activity, and the final recovery was $8 \%$. A similar behaviour was observed in preparations of aromatic aminopeptidases from barley seedlings, wheat leaves, grapes, and pea seeds, where a considerable drop in the total activity was accompanied by a final recovery of $1.5-13 \%$ (Elleman 1974; Kang et al. 1999; Ogiwara et al. 2005; Waters and Dalling 1984). Neither fractionation with acetone nor acidification of the extract with acetic acid yielded the desired results, whereas the treatment with ammonium sulphate, as in the cases of Hordeum vulgare and Vitis labruscana (Kang et al. 1999; Kolehmainen and Mikola 1971), allowed initial pre-purification of Phe-AP, accompanied by a twofold increase in the specific activity.

Purified phenylalanine aminopeptidase from pea was a monomer of molecular weight approximately $60 \mathrm{kDa}$, similar to the weight of aromatic aminopeptidases occurring in other plants. For instance, the weight of AP1 from Triticum aestivum was $57 \mathrm{kDa}$ (Waters and Dalling 1984), AP1 from Zea mays was $61.3 \mathrm{kDa}$ (Vodkin and Scandalios 1980), AP1 of pea seeds was $58 \mathrm{kDa}$ (Elleman 1974), and aromatic aminopeptidase from Vintis vinitafera was $71 \mathrm{kDa}$ (Kang et al. 1999). It ought to be noted that typical leucine aminopeptidases are characterised by a hexameric structure and weight over $250 \mathrm{kDa}$ (Matsui et al. 2006).

Studies of the substrate specificity of Phe-AP purified from pea shoots were carried out with different amino acid derivatives of $\beta$-naphthylamide and of $p$-nitroanilide. The results clearly indicate a similarly to other aromatic aminopeptidases described in the literature (Kang et al. 1999; Kolehmainen and Mikola 1971; Vodkin and Scandalios 1980; Waters and Dalling 1984; Wynn and Murray 1985; Yamaoka et al. 1994); Phe-AP from pea shoots exhibits the highest preference for substrates containing Phe at the N-terminus and is characterised by a high specificity against other aromatic amino acids (Tyr and Trp), as well as the hydrophobic Leu and Met (Table 2). However, it ought to be emphasised that the activity with Leu- $\beta$-NA or Leu- $p$-NA was at least twice lower than that observed with Phe- $\beta$-NA or Phe- $p$-NA, respectively (Kang et al. 1999; 
Waters and Dalling 1984; Wynn and Murray 1985; Yamaoka et al. 1994). In this respect, aromatic aminopeptidases clearly differ from leucine aminopeptidases. The A-type LAPs show 100 times lower activity against substrates with Phe at the N-terminus than against substrates with Leu at the N-terminus (Bartling and Weiler 1992; Gu et al. 1999; Herbers et al. 1994), whereas N-type LAPs are characterised by similar activities against substrates with Phe and with Leu at the N-terminus (Tu et al. 2003). Among the aromatic aminopeptidases only AP1 isolated from pea seeds behaves similarly to LAPs-N, cleaving substrates with N-terminal Phe and Leu in a similar manner (Elleman 1974). A characteristic feature of purified Phe-AP and of the aromatic aminopeptidases described in the literature was their very low or undetectable activity against substrates with Ala, Gly, Arg, Lys, Glu, or Asp at the N-terminus (Kolehmainen and Mikola 1971; Liu and Jagendorf 1986; Scandalios and Espiritu 1969; Wynn and Murray 1985; Yamaoka et al. 1994). The slight preference for substrates with $\mathrm{N}$-terminal Arg is another feature indicating the disparate natures of aromatic aminopeptidases and leucine aminopeptidases (Bartling and Weiler 1992; Tu et al. 2003). The claim that the enzyme in question is phenylalanine aminopeptidase is supported by its low $K_{\mathrm{m}}$ value for Phe- $\beta$-NA of $7.5 \times 10^{-5} \mathrm{M}$ (Table 2). The lowest $K_{\mathrm{m}}$ values for Phe- $\beta$-NA amongst the substrates tested were also obtained for wheat $\left(2 \times 10^{-4} \mathrm{M}\right.$ ) (Waters and Dalling 1984) and barley $\left(3.1 \times 10^{-5} \mathrm{M}\right)$ (Kolehmainen and Mikola 1971) aromatic aminopeptidases.

The optimum $\mathrm{pH}$ for enzyme activity was 7.5 (Fig. 4). This result is similar to the value obtained for aromatic aminopeptidase isolated from grapes ( $\mathrm{pH} 7.0$; Kang et al. 1999), from wheat ( $\mathrm{pH} 7.6$; Waters and Dalling 1984), and from barley ( $\mathrm{pH} 7.2$; Kolehmainen and Mikola 1971). In comparison, leucine aminopeptidases (LAP-A and LAP-N) exhibit the highest activity at alkaline $\mathrm{pH}(\mathrm{pH}$ 8.0-11.0; Matsui et al. 2006).

The optimum temperature for the activity of Phe-AP from pea shoots was determined to be $37^{\circ} \mathrm{C}$, and considerable sensitivity of the purified enzyme to temperature corresponded to data from the literature regarding this group of enzymes (Ogiwara et al. 2005; Waters and Dalling 1984). Unlike aromatic aminopeptidases, leucine aminopeptidases remain stable even at temperatures over $60^{\circ} \mathrm{C}$, and their activities are characterised by an optimum temperature of $60-70^{\circ} \mathrm{C}$ (Matsui et al. 2006).

All the available literature data describing the effect of specific peptidase inhibitors on activity of aromatic aminopeptidases indicate that they are thiol-dependent peptidases. This assumption is confirmed by the total or considerable drop in activity in the presence of such inhibitors as $p \mathrm{CMB}$ ( $p$-chloromercuribenzoic acid) and NEM ( $N$-ethylmaleimide), and the heavy metal ions $\mathrm{Cu}^{2+}$ and $\mathrm{Zn}^{2+}$ (Elleman 1974; Kang et al. 1999; Kolehmainen and Mikola 1971; Tishinov et al. 2009; Waters and Dalling 1984). The majority of aromatic aminopeptidases are partially suppressed in the presence of serine peptidase inhibitors, such as PMSF and/or DFP, which suggests the participation of the hydroxyl groups in catalysis or in the maintenance of protein stability (Kang et al. 1999; Ogiwara et al. 2005; Tishinov et al. 2009). The impact of the applied diagnostic inhibitors of serine and thiol-dependent proteases on Phe-AP from pea shoots confirms that it belongs to the group of aromatic aminopeptidases; however, the effect of the factors that modify the hydroxyl groups is much stronger in comparison to other enzymes from this group. In contrast, AP1 from pea seeds was not suppressed in the presence of serine peptidase inhibitors (Elleman 1974). The metallopeptidase inhibitors EDTA and 1,10-phenanthroline were found to be ineffective at reducing the activity of PheAP and aromatic aminopeptidases isolated from wheat leaves, grapes, sunflower seeds, and cotyledons of cowpea (Kang et al. 1999; Tishinov et al. 2009; Waters and Dalling 1984; Wynn and Murray 1985). This disproves the idea that aromatic aminopeptidases belong to the group of leucine aminopeptidases, which are classified as belonging to the M17 metallopeptidase family (Matsui et al. 2006; Walling and $\mathrm{Gu}$ 1996). However, amongst aminopeptidases that prefer substrates with $\mathrm{N}$-terminal Phe there was one exception to this pattern. This was the AP3 aminopeptidase isolated from the stroma of pea chloroplasts, which was entirely inhibited in the presence of $2 \mathrm{mM} 1,10$ phenanthroline, suggesting that it is a metalloproteinase (Liu and Jagendorf 1986).

The databases contain no sequences (nucleotide or amino acid) for any enzyme from the group of the monomeric thiol-dependent plant aminopeptidases. Therefore, it is not entirely surprising that the analysed in this study by mass spectrometry Phe-AP peptides were assigned to amino acid sequences of hexameric leucine aminopeptidases that are available in the databases. What is startling, however, is the possible high degree of identity between the aligned sequences. AtLAP1 is a leucine aminopeptidase with a homohexameric structure, which belongs to the M17 metallopeptidase family (Bartling and Weiler 1992) and, according to the criteria suggested by $\mathrm{Tu}$ et al. (2003), possesses the amino acid signature characteristic of LAP-N polypeptides. Like other plant $L A P-N$-like genes, AtLAPI is constitutively expressed in all tissues investigated (Bartling and Nosek 1994; Tu et al. 2003 and references therein), and the presence of LAP-N-like proteins was detected in all plant species tested (Chao et al. 2000). The presence of activities characteristic of LAP-N and aromatic aminopeptidases was detected both in monocotyledons and dicotyledons and at almost every stage of ontogenesis (Walling and Gu 1996). The prevalence of both of these 
groups of enzymes suggests that they are important for basic catabolism of peptides and proteins. However, only the elucidation of the full sequences of monomeric aminopeptidases will allow the identification of differences in the nucleotide and amino acid sequences determining the different structures and catalytic properties of those groups of enzymes.

Open Access This article is distributed under the terms of the Creative Commons Attribution Noncommercial License which permits any noncommercial use, distribution, and reproduction in any medium, provided the original author(s) and source are credited.

\section{References}

Bartling D, Nosek J (1994) Molecular and immunological characterization of leucine aminopeptidase in Arabidopsis thaliana: a new antibody suggests a semi-constitutive regulation of a phylogenetically old enzyme. Plant Sci 9:199-209

Bartling D, Weiler EW (1992) Leucine aminopeptidase from Arabidopsis thaliana. Molecular evidence for a phylogenetically conserved enzyme of protein turnover in higher plants. Eur $\mathrm{J}$ Biochem 205:425-431

Bradford MM (1976) A rapid and sensitive method for the quantitation of microgram quantities of protein utilizing the principle of protein-dye binding. Anal Biochem 72:248-254

Burley SK, Dawid PR, Taylor A, Libscomb WN (1990) Molecular structure of leucine aminopeptidase at $2.7-\AA$ resolution. Proc Natl Acad Sci USA 87:6878-6882

Chao WS, Pautot V, Holzer FM, Walling LL (2000) Leucine aminopeptidases: the ubiquity of LAP-N and the specificity of LAP-A. Planta 210:563-573

Collier MD, Murray DR (1977) Leucyl $\beta$-naphthylamidase activities in developing seeds and seedlings of Pisum sativum L. Aust J Plant Physiol 4:571-582

Elleman TC (1974) Aminopeptidases of pea. Biochem J 141:113-118

Fowler JH, Narváez-Vásquez J, Aromdee DN, Pautot V, Holzer FM, Walling LL (2009) Leucine aminopeptidase regulates defense and wound signaling in tomato downstream of jasmonic acid. Plant Cell 21:1239-1251

Gu Y-Q, Walling LL (2000) Specificity of the wound-induced leucine aminopeptidase (LAP-A) of tomato. Activity on dipeptide and tripeptide substrates. Eur J Biochem 267:1178-1187

Gu Y-Q, Walling LL (2002) Identification of residues critical for activity of the wound-induced leucine aminopeptidase (LAP-A) of tomato. Eur J Biochem 269:1630-1640

Gu Y-Q, Pautot V, Holzer FM, Walling LL (1996) A complex array of proteins related to the multimeric leucine aminopeptidase of tomato. Plant Physiol 110:1257-1266

Gu Y-Q, Holzer FM, Walling LL (1999) Overexpression, purification and biochemical characterization of the wound-induced leucine aminopeptidase of tomato. Eur J Biochem 263:726-735
Herbers K, Prat S, Willmitzer L (1994) Functional analysis of a leucine aminopeptidase from Solanum tuberosum L. Planta 194:230-240

Hoagland DR, Arnon DI (1938) The water culture method for growing plants without soil. Calif Agric Exp Stn Circ 347:1-39

Kang H-C, Hahn T-R, Chung I-S, Park J-C (1999) Characterization of an aminopeptidases from grapes. Int J Plant Sci 160:299-306

Kim H, Lipscomb WN (1994) Structure and mechanism of bovine lens leucine aminopeptidase. Adv Enzymol Relat Areas Mol Biol 68:153-213

Kolehmainen L, Mikola J (1971) Partial purification and enzymatic properties of an aminopeptidases from barley. Arch Biochem Biophys 145:632-642

Laemmli UK (1970) Cleavage of structural proteins during the assembly of the head of bacteriophage T4. Nature 227:680-685

Lineweaver M, Burk DJ (1934) The determination of enzyme dissociation constants. J Am Chem Soc 56:658-666

Liu X-Q, Jagendorf AT (1986) Neutral peptidases in the stroma of pea chloroplasts. Plant Physiol 81:603-608

Matsui M, Fowler JH, Walling LL (2006) Leucine aminopeptidases: diversity in structure and function. Biol Chem 387:1535-1544

Ogiwara N, Amano T, Satoh M, Shioi Y (2005) Leucine aminopeptidase from etiolated barley seedlings: characterization and partial purification of isoforms. Plant Sci 168:575-581

Rawlings ND, Barrett AJ, Bateman A (2010) MEROPS: the peptidase database. Nucleic Acids Res 38:D227-D233

Scandalios JG, Espiritu LG (1969) Mutant aminopeptidases of Pisum sativum. I. Developmental genetics and chemical characteristic. Mol Gen Genet 105:101-112

Sopanen T, Mikola J (1975) Purification and partial characterization of barley leucine aminopeptidase. Plant Physiol 55:809-814

Taylor A (1993) Aminopeptidases: structure and function. FASEB J 7:290-298

Tishinov K, Stambolieva N, Petrova S, Galunsky B, Nedkov P (2009) Purification and characterization of the sunflower seed (Helianthus annuus L.) major aminopeptidase. Acta Physiol Plant 31:199-205

Tu CJ, Park SY, Walling LL (2003) Isolation and characterization of the neutral leucine aminopeptidase (LapN) of tomato. Plant Physiol 132:243-255

Vodkin LO, Scandalios JG (1980) Comparative properties of genetically defined peptidases in maize. Biochemistry 19:4660-4667

Walling LL (2006) Recycling or regulation? The role of aminoterminal modifying enzymes. Curr Opin Plant Biol 9:227-233

Walling LL, Gu Y-Q (1996) Plant aminopeptidases: occurrence, function and characterization. In: Taylor A (ed) Aminopeptidases. RG Landes Co, Austin, pp 174-219

Waters SP, Dalling MJ (1984) Isolation and some properties of an aminopeptidase from the primary leaf of wheat. Plant Physiol 75:118-124

Wynn EK, Murray DR (1985) Aminopeptidases isolated from cotyledons of cowpea, Vigna unguiculata. Ann Bot 56:55-60

Yamaoka Y, Takeuchi M, Morohashi Y (1994) Purification and partial characterization of an aminopeptidase from mung bean cotyledons. Physiol Plant 90:729-733 